\title{
KEBIJAKAN PENDIDIKAN DASAR GRATIS \\ (STUDI KOMPARASI DI SD DAN MI DI YOGYAKARTA)
}

\section{Oleh: Aqodiah \\ ORIENTASI PROFESIONALISME DAN PROSFEKSI MASA DEPAN (Pendidikan Guru Madrasah Ibtidaiyah (PGMI))}

\author{
Oleh: Riadi \\ Sekretaris jurusan PGMI Universitas Muhammadiyah Mataram. Alamat: Dusun Tibu \\ Ambung. desa Lembah Sari. kantor Jalan KH.Ahmad Dahlan No. 1 Pagesangan Mataram. \\ Email: riadisaepudin@yahoo.com.
}

\section{Pendahuluan: Antara Profesionalisme atau Budaya Pragmatisme}

Pendidikan seperti kata dasar yang melekat yakni 'didik' memiliki makna mewariskan 'nilai-nilai luhur' sekaligus diproyeksikan menjadi modal bagi orang yang terdidik. Secara formal, semua tahu akan masa depan putera-puteri bangsa dalam tanggung jawab orang yang mendidik. Akan tetapi, orang yang menjadi guru di lembaga formal (negeri) sekalipun dan memiliki kesadaran akan masa depan anak dalam tanggung jawabnya, terkadang masih menyelenggarakan proses pembelajaran yang kurang menunjukkan profesionalitas. Hasil tidak akan terlepas dari proses yang dijalani, karenanya baik-buruk hasil pendidikan sangat ditentukan oleh proses yang dipraktikkan.

Kurang satu dasawarsa yang lalu, semua orang bisa menjadi guru, baik dari jurusan non pendidikan sampai guru yang tidak kualifikasi sarjana. Tradisi tersebut berlangsung cukup lama, mengakibatkan hasil pendidikan saat ini belum mencapai tujuan yang diinginkan atau setidaknya saat ini guru yang puluhan tahun bergelut dengan anak didiknya 'kejar-kejaran' menyelesaikan pendidikan strata satunya dengan berbagai motif.

Madrasah sampai dewasa ini hanya memiliki prestasi secara kuantitas (dimana-mana ada madrasah), akan tetapi belum menunjukkan prestasi secara 
kualitas bila dibanding dengan sekolah pada umumnya. Hal tersebut tidak terlepas dari SDM yang memotori kendali maju-mundur-stagnan nya lembaga tersebut.

Problematika madrasah di atas, sebagiannya sudah dibenahi sejak dulu bahkan seusia madrasah itu sendiri, akan tetapi terobosan pembenahan belum secara khusus membidik akar masalah. Akar masalah Madrasah tidak lain dan tidak bukan adalah persoalan SDM baik barisan belakang layar (managemen) maupun ujung tombak seperti tenaga pendidik dan kependidikannya.

Kehadiran jurusan PGMI merupakan satu terobosan baru yang mencoba menembak akar masalah madrasah yaitu para guru. Selama ini guru madrasah dikesankan kurang profesional dibanding guru pada umumnya dan tingkat kesejahteraannya pun masih tidak menjanjikan dibanding kesejahteraan guru lainnya. Oleh karena itu, PGMI sebagai sebuah jurusan memberikan kepastian membentuk profesionalisme guru guna mendongkrak kesan baik di tengah masyarakat sekaligus PGMI menjawab budaya pragmatis masyarakat seiring semakin sulitnya mengukir masa depan.

PGMI sebagai jurusan baru tentu memiliki keunggulan bila dibanding dengan jurusan yang lain. Keunggulannya antara lain pertama memiliki titik fokus untuk pembekalan profesionalitas guru, guru sebagai sebuah profesi harus dimaknai sebagai pekerjaan yang harus dilakoni oleh orang yang ahli, memiliki loyalitas tinggi dan kapabilitas yang mumpuni. Kedua peningkatan kualitas pembelajaran, selama ini madrasah terkesan diajarkan dengan metode monoton kurang inovatif dan kreatif. PGMI sebagai jurusan pendidikan guru membekali guru berbagai model pembelajaran sehingga kesan 'miskin' kreatifitas menjadi berubah 'mendadak kaya' kreatifitas. Keunggulan ketiga barangkali bila dilihat dari peluang kerja maka PGMI bisa dikatakan mampu menjawab cita-cita masyarakat yang pragmatis. Kebaruan jurusan ini menjadikan peluang kerja lebih besar dan menjanjikan bila dibanding dengan jurusan lainnya.

\section{Orientasi PGMI: Menghasilkan Sarjana Guru Kelas Profesional}


Dalam undang-undang guru dan dosen no. 14 tahun 2005 pada pasal 1 disebutkan guru adalah pendidik profesional dengan tugas utama mendidik, mengajar, membimbing, mengarahkan, melatih, menilai, dan mengevaluasi peserta didik pada pendidikan anak usia dini jalur pendidikan formal, pendidikan dasar, dan pendidikan menengah. Jadi, guru adalah orang yang memiliki keahlian menjadi guru yang sebelumnya menjadi objek pendidikan dan selanjutnya menjadi subjek pendidikan.

Sedangkan guru professional sebagaimana disebutkan oleh HAR Tilaar adalah bukan hanya sekedar alat untuk transmisi kebudayaan tetapi mentransformasikan kebudayaan itu ke arah budaya yang dinamis yang menuntut penguasaan ilmu pengetahuan, produktifitas yang tinggi, dan kualitas karya yang dapat bersaing. Guru profesional bukan lagi merupakan sosok yang berfungsi sebagai robot, tetapi merupakan dinamisator yang mengantar potensi-potensi peserta didik ke arah kreatifitas. ${ }^{1}$ Sebelumnya dididik, diajar, dibimbing, diarahkan, dilatih, dinilai dan dievaluasi selanjutnya menjadi mendidik, mengajar, membimbing, mengarahkan, melatih, menilai dan mengevaluasi. Bila sebelumnya tidak pernah menjadi objek (dididik, diajar, dibimbing, diarahkan, dilatih, dinilai dan dievaluasi) maka mustahil 'guru' menjadi profesi seseorang. Menurut Hamzah B. Uno, guru merupakan suatu profesi yang berarti suatu jabatan yang memerlukan keahlian khusus sebagai guru dan tidak dapat dilakukan oleh sembarang orang di luar bidang pendidikan. Walaupun pada kenyataannya terdapat hal-hal tersebut di luar bidang kependidikan. ${ }^{2}$ Idealnya sarjana pendidikan (S. Pd) sangat berhak menjadi guru ketimbang sarjana sosial (S. Sos) atau sarjana hukum (SH) sebagaimana yang menjangkiti madrasah saat ini. Orientasi yang diinginkan pada jurusan PGMI adalah orientasi yang dikehendaki oleh undang-undang. Bila kecilnya bercita-cita menjadi guru madrasah yang profesional maka bergabunglah pada jurusan ini.

\footnotetext{
${ }^{1}$ H. A. R. Tilaar, Membenahi Pendidikan Nasional, (Jakarta: Rineka Cipta, 2002), hlm. 88.

${ }^{2}$ Hamzah B. Uno, Profesi Kependidikan, Problem, Solusi dan Reformasi Pendidikan di Indonesia, (Jakarta: Bumi Aksara, 2008), hlm.15.
} 
Menjadi profesional dalam segala bidang menjadi cita-cita setiap individual bahkan cita-cita nasional. Secara individual, tidak ada satu orang pun yang bercitacita menjadi individu yang kurang kemampuan walaupun seyogyanya banyak orang yang memiliki keterbatasan kemampuan dalam bidangnya sekalipun. Sedangkan secara nasional, pemerintah saat ini serius melakukan penataan kualitas sumber daya manusia sebagaimana dituangkan dalam berbagai undang-undang.

\section{Orientasi PGMI: Menghasilkan guru yang kualifikatif}

Menjadi guru tidak cukup bermodal kharisma (formalistik) semata namun wajib memiliki kemampuan akademis yang ditunjang dengan kualifikasi kesarjanaan. Setinggi apapun ilmu seseorang apabila belum menjadi sarjana maka belum layak disebut menjadi guru profesional. Kualifikasi sarjana menjadi syarat mutlak menjadi guru. Untuk menjunjung tinggi idealitas undang-undang sebagai regulasi yang sudah ditetapkan oleh pemerintah maka syarat tersebut harus pula diapresiasi setinggitingginya dengan menutup ruang bagi calon guru yang tidak memenuhi kualifikasi menjadi guru. Sedangkan bagi seorang guru yang tidak memenuhi kualifikasi maka ada dua alternatif yakni mengundurkan diri atau menempuh pendidikan sampai mencapai gelar sarjana. Sarjananya pun harus sesuai dengan jalur pendidikan, hal ini dilakukan agar tidak ada lagi cerita sarjana (non pendidikan) banting setir menjadi guru. Profesi guru bukanlah profesi pelarian, bukan pula profesi sampingan tetapi profesi guru adalah profesi yang harus dijunjung di atas profesionalisme.

Salah satu kelemahan madrasah sejak keberadaannya sampai sekarang adalah tidak memiliki standar akademis yang baku. Justru madrasah latah dengan standar yang kaku, jauh dari istilah professional dan akrab dengan istilah tradisionalkonvensional. Tidak berlebihan bila diistilahkan demikian mengingat data lapangan menunjukkan bahwa guru madrasah banyak mengajar mata pelajaran yang tidak sesuai dengan kesarjanaannya (missmatch), istilah konvensional menunjukkan bahwa madrasah (kepala madrasah) tidak memiliki kemerdekaan untuk memberikan 
keputusan apapun sebelum keputusan pengelola yayasan. Bila hal tersebut berani ditinggalkan maka madrasah pasti akan maju.

PGMI sebagai sebuah jurusan bertekad memperbaiki kualitas madrasah yang selama ini dimakan usia tanpa karya. PGMI menyiapkan apa yang dibutuhkan bagi calon guru madrasah sesuai tuntutan undang-undang. Diantaranya mencetak guru yang memiliki kualifikasi menjadi guru di madrasah. Satu-satunya jurusan yang secara tegas mencetak guru madrasah professional. Sehingga perlu keyakinan dari kita semua bahwa bila sudah tersirat dalam niat untuk memperbaiki kualitas madrasah, maka PGMI adalah solusi meski bukanlah satu-satunya solusi.

\section{Orientasi PGMI: Menghasilkan guru yang kompeten dibidangnya}

Apabila suatu urusan diberikan kepada yang bukan ahlinya, maka tunggulah saat-saat kehancuran. Kurang lebih demikian bunyi salah satu hadits yang tidak asing lagi di telinga para pengelola lembaga pendidikan semisal madrasah. Makna Hadits ini sangat penting mengingat madrasah banyak dikelola oleh orang-orang bukan ahlinya sehingga hasilnya pun begitu-begitu saja, jalan di tempat, stagnan, bahkan banyak cerita madrasah gulung tikar karena tidak memiliki siswa/siswi baru. Belum banyak madrasah yang membanggakan dengan memberikan prestasi apalagi madrasah yang berada dipinggiran. Kecuali madrasah-madrasah yang berlabel negeri secara tersendiri memiliki perlakuan berbeda dari pemerintah.

Berbagai kelemahan yang ada dalam tubuh madrasah secara pelan tapi pasti akan teratasi seiring keberadaan jurusan PGMI. Karenanya apa yang menjadi kebutuhan di madrasah sedini mungkin sudah diakomodir pada jurusan ini. Setidaktidaknya guru SD/MI harus menguasai standar kompetensi dan kompetensi dasar mata pelajaran/bidang pengembangan yang diampu. Standar kompetensi dan 
kompetensi dasar yang dimaksud adalah lima mata pelajaran SD/MI yakni Bahasa Indonesia, Matematika, IPA, IPS dan PKn. ${ }^{3}$

\begin{tabular}{|c|c|}
\hline \multicolumn{2}{|c|}{ KOMPETENSI GURU KELAS SD/MI } \\
\hline MATA PELAJARAN & KOMPETENSI YANG HARUS DIKUASAI \\
\hline BAHASA INDONESIA & $\begin{array}{l}\text { 1. Memahami hakikat bahasa dan pemerolehan bahasa. } \\
\text { 2. Memahami kedudukan, fungsi, dan ragam bahasa } \\
\text { Indonesia. } \\
\text { 3. Menguasai dasar-dasar dan kaidah bahasa Indonesia } \\
\text { sebagai rujukan penggunaan bahasa Indonesia yang baik } \\
\text { dan benar. } \\
\text { 4. Memiliki keterampilan berbahasa Indonesia (menyimak, } \\
\text { berbicara, membaca, dan menulis) } \\
\text { 5. Memahami teori dan genre sastra Indonesia. } \\
\text { 6. Mampu mengapresiasi karya sastra Indonesia, secara } \\
\text { reseptif dan produktif. }\end{array}$ \\
\hline МАТЕМАТIKA & $\begin{array}{l}\text { 1. Menguasai pengetahuan konseptual dan prosedural serta } \\
\text { keterkaitan keduanya dalam konteks materi aritmatika, } \\
\text { aljabar, geometri, trigonometri, pengukuran, statistika, dan } \\
\text { logika matematika. } \\
\text { 2. Mampu menggunakan matematisasi horizontal dan } \\
\text { vertikal untuk menyelesaikan masalah matematika dan } \\
\text { masalah dalam dunia nyata. } \\
\text { 3. Mampu menggunakan pengetahuan konseptual, } \\
\text { prosedural, dan keterkaitan keduanya dalam pemecahan } \\
\text { masalah matematika, serta. penerapannya dalam } \\
\text { kehidupan sehari-hari. } \\
\text { 4ampu menggunakan alat peraga, alat ukur, alat hitung, } \\
\text { dan piranti lunak komputer. }\end{array}$ \\
\hline IPA & $\begin{array}{l}\text { 1. Mampu melakukan observasi gejala alam baik secara } \\
\text { langsung maupun tidak langsung. } \\
\text { 2. Memanfaatkan konsep-konsep dan hukum-hukum ilmu } \\
\text { pengetahuan alam dalam berbagai situasi kehidupan } \\
\text { sehari-hari. }\end{array}$ \\
\hline
\end{tabular}

${ }^{3}$ Lebih lengkapnya baca peraturan menteri pendidikan nasional Republik Indonesia nomor 16 tahun 2007 tentang standar kualifikasi akademik dan kompetensi guru dan standar kompetensi guru kelas SD/MI tahun 2006. 


\begin{tabular}{|c|c|}
\hline & $\begin{array}{l}\text { 3. Memahami struktur ilmu pengetahuan alam, termasuk } \\
\text { hubungan fungsional antarkonsep, yang berhubungan } \\
\text { dengan mata pelajaran IPA. }\end{array}$ \\
\hline IPS & $\begin{array}{l}\text { 1. Menguasai materi keilmuan yang meliputi dimensi } \\
\text { pengetahuan, nilai, dan keterampilan IPS. } \\
\text { 2. Mengembangkan materi, struktur, dan konsep keilmuan } \\
\text { IPS. } \\
\text { 3. Memahami cita-cita, nilai, konsep, dan prinsip-prinsip } \\
\text { pokok ilmu-ilmu sosial dalam konteks kebhinnekaan } \\
\text { masyarakat Indonesia dan dinamika kehidupan global. } \\
\text { 4. Memahami fenomena interaksi perkembangan ilmu } \\
\text { pengetahuan, teknologi, seni, kehidupan agama, dan } \\
\text { perkembangan masyarakat serta saling ketergantungan } \\
\text { global. }\end{array}$ \\
\hline PKn & $\begin{array}{l}\text { 1. Menguasai materi keilmuan yang meliputi dimensi } \\
\text { pengetahuan, sikap, nilai, dan perilaku yang mendukung } \\
\text { kegiatan pembelajaran PKn. } \\
\text { 2. Menguasai konsep dan prinsip kepribadian nasional dan } \\
\text { demokrasi konstitusional Indonesia, semangat kebangsaan } \\
\text { dan cinta tanah air serta bela negara. } \\
\text { 3. Menguasai konsep dan prinsip perlindungan, pemajuan } \\
\text { HAM, serta penegakan hukum secara adil dan benar. } \\
\text { 4. Menguasai konsep, prinsip, nilai, moral, dan norma } \\
\text { kewarganegaraan Indonesia yang demokratis dalam } \\
\text { konteks kewargaan negara dan dunia. }\end{array}$ \\
\hline
\end{tabular}

Dalam pengembangan jurusan PGMI mustinya kelima mata pelajaran tersebut menjadi acuan atau stressing agar mahasiswa jurusa PGMI memiliki/menguasai kelima mata pelajaran tersebut. Sehingga lebih dini harus disadari bahwa menjadi guru itu kaitannya dengan masa depan anak, jangan sampai anak dijadikan 'kelinci percobaan' dan akhirnya masa depan anak menjadi korban. PGMI dengan visi dan misinya berupaya mencetak guru-guru yang kompeten di bidangnnya. Dalam hal ini, menarik mengutip pendapat Ngainun Naim yang menjelaskan bahwa secara prinsip, mereka yang disebut sebagai guru bukan hanya mereka yang memiliki kualifikasi keguruan secara formal yang diperoleh lewat jenjang pendidikan di perguruan tinggi saja, tetapi yang terpenting adalah mereka yang mempunyai kompetensi keilmuan tertentu dan dapat menjadikan orang lain pandai dalam matra kognitif, afektif dan psikomotorik. Matra kognitif menjadikan siswa cerdas dalam aspek intelektualnya, 
matra afektif menjadikan siswa mempunyai sikap dan perilaku yang sopan dan matra psikomotorik menjadikan siswa terampil dalam melaksanakan aktifitas secara efektif dan efisien serta tepat guna. ${ }^{4}$ Ketiga matra yang dijelaskan oleh Ngainun Naim di atas, dalam Permen nomor 64 tahun 2013 tentang Standar Isi Pendidikan Dasar dan Menengah ditentukan berdasarkan tingkat kompetensi yang bersifat generik. Selanjutnya disebutkan tingkat kompetensi yang bersifat generik tersebut mencakup tiga ranah yakni sikap, pengetahuan dan keterampilan.

Menurut peraturan pemerintah no 32 tahun 2013 tentang Standar Nasional Pendidikan pasal 77H disebutkan bahwa struktur kurikulum pendidikan dasar berisi muatan pembelajaran atau mata pelajaran yang dirancang untuk mengembangkan kompetensi spiritual keagamaan, sikap personal dan sosial, pengetahuan, dan keterampilan. Sedangkan pasal 77I disebutkan bahwa struktur kurikulum SD/MI, SDLB atau bentuk lain yang sederajat terdiri atas muatan: Pendidikan Agama, Pendidikan Kwarganegaraan, Bahasa, Matematika, Ilmu Pengetahuan Alam, Ilmu Pengetahuan Sosial, Seni dan Budaya, Pendidikan Jasmani dan Olahraga, Keterampilan/Kejuruan dan Muatan Lokal.

Untuk mata pelajaran pendidikan agama (Islam) dikembangkan menjadi mata pelajaran Al-Quran, Aqidah, Akhlak dan Budi Pekerti, Fiqih dan Sejarah Peradaban Islam pada tingkat kompetensi 1 dan 2 untuk kelas I-IV. Sedangkan pada tingkat kompetensi 3 untuk kelas V-VI terdiri dari Al-Quran, Aqidah, Akhlak dan Budi Pekerti, Fiqih. ${ }^{5}$

Mengacu pada tingkat kompetensi yang ada, maka SD/MI masuk pada kategori tingkat kompetensi 1-3. Kompetensi 1 untuk tingkat kelas 1 dan 2, sedangkan kompetensi 2 untuk tingkat kelas 3 dan 4 dan kompetensi 3 untuk tingkat kelas 5 dan 6.

Tabel 2. Tingkat Kompetensi dan Tingkat Kelas

\begin{tabular}{|l|l|l|}
\hline NO & TINGKAT KOMPETENSI & TINGKAT KELAS \\
\hline 1 & Tingkat 1 & $\begin{array}{l}\text { Kelas I SD/MI sederajat } \\
\text { Kelas II SD/MI sederajat }\end{array}$ \\
\hline 2 & Tingkat 2 & Kelas III SD/MI sederajat \\
\hline
\end{tabular}

\footnotetext{
${ }^{4}$ Ngainun Naim, Menjadi Guru Inspiratif Memberdayakan dan Mengubah Jalan Hidup Siswa, (Yogyakarta: Pustaka Pelajar, 2009), hlm. 4.

${ }^{5}$ Lebih lengkapnyaterkait dengan kompetensi masing-masing muatan pelajaran, lihat Permen No 64 Tahun 2013 tentang Standa Isi Pendidikan Dasar dan Menengah.
} 


\begin{tabular}{|l|l|l|}
\hline & & Kelas IV SD/MI sederajat \\
\hline 3 & Tingkat 3 & $\begin{array}{l}\text { Kelas V SD/MI sederajat } \\
\text { Kelas VI SD/MI sederajat }\end{array}$ \\
\hline
\end{tabular}

Dengan demikian semakin tinggi tingkat kelas yang ditempuh maka semakin tinggi pula tingkat kompetensi yang harus diselesaikan dan semakin tinggi tingkat kompetensi yang ditempuh maka semakin rumit dan kompleks intensitas pengalaman belajar peserta didik, proses pembelajaran dan penilaian yang dihadapi.

Kompetensi yang bersifat generik mencakup tiga ranah yakni sikap, pengetahuan dan keterampilan. Ranah sikap dipilah menjadi sikap spiritual dan sikap sosial. Dengan demikian, kompetensi yang bersifat generik terdiri atas empat dimensi yang mempresentasikan sikap spiritual, sikap sosial, pengetahuan dan keterampilan. Untuk lebih jelasnya, berikut ditampilkan sebuah tabel yang menggambarkan keempat ranah tersebut.

Tabel 3. Kompetensi dan Deskripsi Kompetensi

\begin{tabular}{|c|c|c|c|}
\hline $\begin{array}{l}\mathbf{N} \\
\mathbf{0}\end{array}$ & $\begin{array}{l}\text { Tingkat } \\
\text { kompetens } \\
\text { i \& kelas }\end{array}$ & Kompetensi & Deskripsi Kompetensi \\
\hline \multirow{4}{*}{1} & \multirow{4}{*}{$\begin{array}{l}\text { Tingkat } 1 \\
\text { Kelas I dan } \\
\text { II SD/MI }\end{array}$} & Sikap spiritual & $\begin{array}{l}\text { 1. Menerima dan menjalankan ajaran agama yang } \\
\text { dianutnya }\end{array}$ \\
\hline & & Sikap sosial & $\begin{array}{l}\text { 2. Menunjukkan prilaku jujur, disiplin, tanggung } \\
\text { jawab, santun, peduli dan percaya diri dalam } \\
\text { berinteraksi dengan keluarga, teman dan guru. }\end{array}$ \\
\hline & & Pengetahuan & $\begin{array}{l}\text { 3. Memahami pengetahuan factual dengan cara } \\
\text { mengamati (mendengar, melihat, membaca) dan } \\
\text { menanya berdasarkan rasa ingin tahu tentang } \\
\text { dirinya, makhluk ciptaan Tuhan dan kegiatannya } \\
\text { dan benda-benda yang dijumpainya di rumah dan } \\
\text { di sekolah. }\end{array}$ \\
\hline & & Keterampilan & $\begin{array}{l}\text { 4. Menyajikan pengetahuan factual dalam bahasa } \\
\text { yang jelas dan logis, dalam karya yang estetis, } \\
\text { dalam gerakan yang mencerminkan anak sehat, dan } \\
\text { dalam tindakan yang mencerminkan prilaku anak } \\
\text { beriman dan berakhlak mulia. }\end{array}$ \\
\hline \multirow[b]{2}{*}{2} & \multirow{2}{*}{\begin{tabular}{ll}
\multicolumn{2}{l}{ Tingkat 2} \\
Kelas & III \\
dan & IV \\
SD/MI &
\end{tabular}} & Sikap spiritual & $\begin{array}{l}\text { 1. Menerima, menjalankan dan menghargai ajaran } \\
\text { agama yang dianutnya }\end{array}$ \\
\hline & & Sikap sosial & $\begin{array}{l}\text { 2. Menunjukkan prilaku jujur, disiplin, tanggung } \\
\text { jawab, santun, peduli dan percaya diri dalam } \\
\text { berinteraksi dengan keluarga, teman, guru dan } \\
\text { tetangganya. }\end{array}$ \\
\hline
\end{tabular}




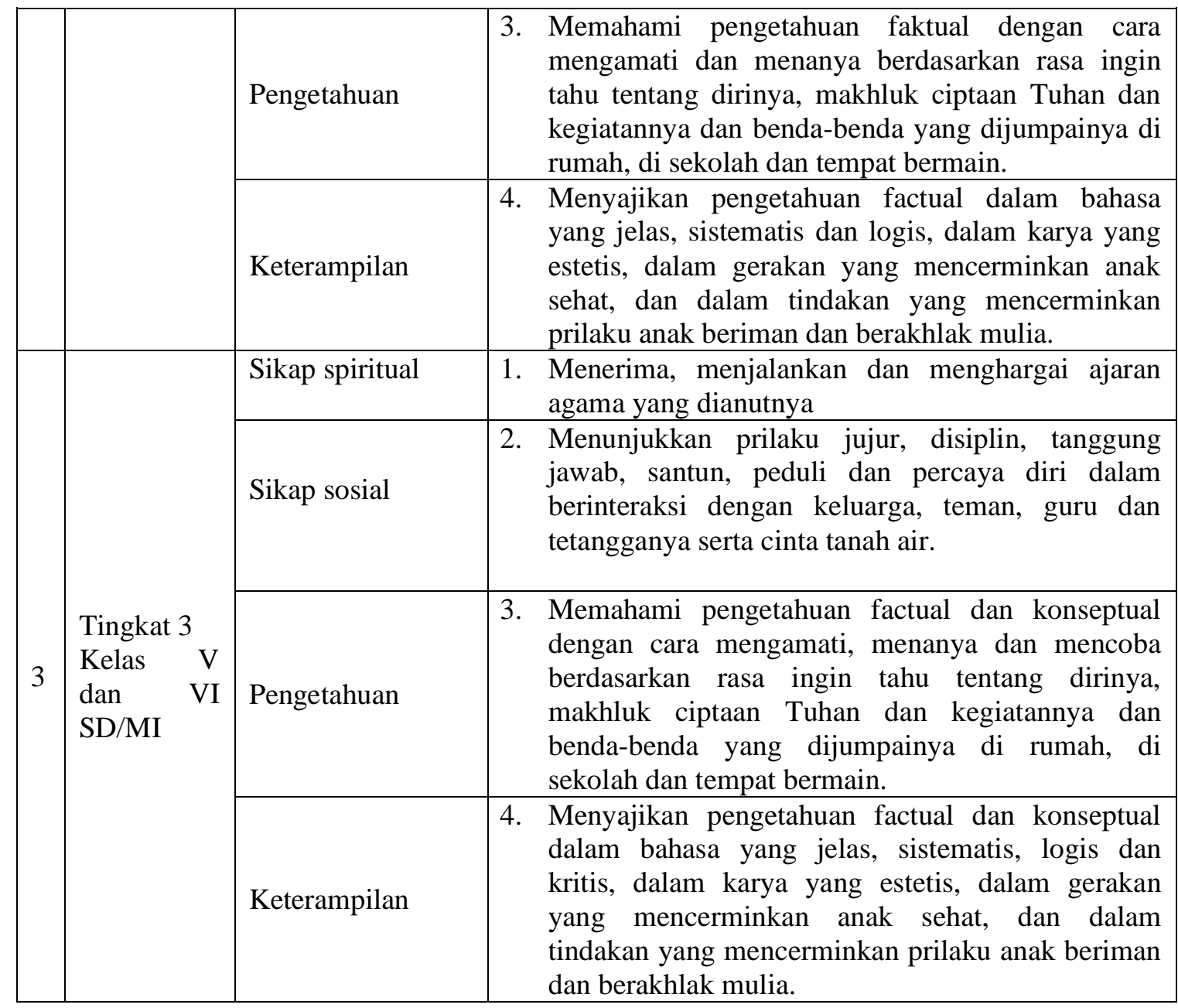

\section{Orientasi PGMI: Penguasaan Pola Pembelajaran}

Ada ungkapan yang sangat menarik mengatakan 'banyak orang yang bekerja menjadi guru akan tetapi sedikit saja orang yang bisa menjadi guru'. Ungkapan ini mengundang rasa penasaran penulis akan kebenarannya. Berat untuk dipercaya akan tetapi itulah data yang ada di lapangan. Selama ini guru madrasah dengan kurangnya kualifikasi yang dimiliki memicu pada pola pembelajaran yang selalu di terapkan di dalam kelas sangat tidak kreatif. Karena kurangnya kualifikasi yang dimiliki oleh guru, sehingga dalam praktiknya sering melakukan hal-hal yang kurang tepat yang menimbulkan suasana yang tidak kondusif. Praktik pembelajaran yang kurang tepat tersebut diantaranya pertama guru tidak berusaha untuk mengetahui kemampuan awal siswa, kedua guru tidak pernah mengajak siswa untuk berfikir, 
ketiga guru tidak berusaha memperoleh umpan balik dan keempat guru menganggap bahwa ia adalah orang yang paling mampu dan menguasai pelajaran (Hamruni, 2009:29).

PGMI sebagai jurusan baru memiliki orientasi untuk memberikan bekal mengajar kepada calon guru secara komprehensif. Sederhananya dalam proses perkuliahan PGMI, dalam sebaran kurikulum banyak mata kuliah yang menyangkut pembelajaran-pembelajaran, semisal pembelajaran MTK, Pembelajaran Sains dan sebagainya.

\section{Prosfeksi PGMI: Strategi menjawab pertanyaan masyarakat}

Selama ini madrasah dianggap sebagai lembaga pendidikan Islam yang mutunya lebih rendah daripada mutu lembaga pendidikan lainnya, terutama sekolah umum, walaupun beberapa madrasah justru lebih maju walaupun sekolah umum. Namun keberhasilan beberapa madrasah dalam jumlah yang terbatas itu belum mampu menghapus kesan negatif yang sudah terlanjur melekat. ${ }^{6}$ Kesan negatif ini tidak hanya pada persoalan sekarang saja melainkan masyarakat sampai memvonis negatif masa depan lulusan madrasah.

Diantaranya pada konteks keilmuan lulusan madrasah tidak lebih baik dibanding lulusan pondok pesantren dan sekolah umum. Dengan kata lain keilmuan lulusan madrasah masih parsial atau setengah-setengah. Setengah---untuk mengatakan sedikit, untuk ilmu agama setengah pula untuk ilmu umum. Belum lagi proses yang ada di madrasah masih butuh perbaikan-perbaikan sehingga wajar bila masyarakat menanyakan-meragukan tentang keilmuan lulusan madrasah sehingga pada ujungnya terlihat pada kesan-kesan yang muncul ke permukaan.

Sedangkan pada konteks dunia kerja, dulunya pernah ada kesan masyarakat bahwa lulusan madrasah tidak siap pakai di dunia kerja. Bahkan dulu pernah ada kekhawatiran masyarakat terhadap lulusan madrasah tidak dibolehkan untuk melanjutkan ke jenjang pendidikan yang lebih tinggi, sampai akhirnya kekhawatiran

\footnotetext{
${ }^{6}$ Mujamil Qomar, Manajemen Pendidikan Islam Strategi Baru Pengelolaan Lembaga Pendidikan Islam, (Malang: Erlangga, 2007), hlm. 79.
} 
semacam itu terjawab dengan dikeluarkannya kesepakatan SKB 3 Menteri pada tahun 1975.

Pertanyaan-pertanyaan tersebut seiring perubahan dalam segala bidang pelan tapi pasti terjawab pula. Bak gayung bersambut, masyarakat bertanya pemerintah menjawab. Berakar pada UU no 20 tahun 2003 tentang sisdiknas dan uu no 14 tahun 2005 tentang guru dan dosen, sekali lagi semuanya berubah. Penulis memiliki keyakinan terhadap pertanyaan-pertanyaan yang serupa bisa terjawab. Sebagai sebuah jawaban secara umumnya adanya jurusan yang secara khusus membenahi kualitas madrasah yakni PGMI. Sehingga kedepannya, secara keilmuan, lulusan madrasah lebih berbobot karena diajar oleh guru lulusan PGMI yang professional, kompeten, kualifikatif. Sedangkan pada konteks dunia kerja, lulusan PGMI memiliki peluang yang sangat besar dibanding jurusan pendidikan lainnya. Mengingat saat ini usia PGMI masih seumur jangung, maka masa suburnya masih panjang.

\section{Prosfeksi PGMI: Jalan pintas menuju sukses}

Budaya pragmatis identik dengan jalan pintas, apa yang dikerjakannya ingin secepat kilat harus segera berbuah manis. Ekspektasi masyarakat terhadap putera-puterinya untuk menjadi orang sukses sangat tinggi akan tetapi semangat menyekolahkan sampai ke perguruan tinggi terkadang sangat rendah. Belum lagi misalnya puteraputerinya menghabiskan waktu kuliah sarjana (S1) sampai delapan tahun tentu waktu

yang sangat lama. Menurut hemat penulis bahwa jalan pintas menjadi sukses itu ada. Secara umum, pendidikan diyakini mampu mengantar seseorang melangkah sukses. Namun demikian bila seisi alam ini menempuh jalur pendidikan sebagai jalur kesuksesan tentu ada kompetisi-kompetisi yang akan dihadapi, dengan demikian penting pula difikirkan bagaimana cara sukses dalam memenangi kompetisi tersebut.

\section{Prosfeksi PGMI: Sukses dunia dan akhirat}

Kelebihan madrasah dibanding dengan sekolah umum adalah terletak pada muatan kurikulum yang ada. Kurikulum madrasah lebih komplit baik untuk pengetahuan 
umum maupun pengetahuan agama. Bahkan dalam sejarah awal madrasah pernah menerapkan kurikulum yang berimbang yakni 100\% ilmu agama dan 100\% ilmu umum. Meski demikian muatan kurikulum yang demikian mendapat kritikan pedas sehingga harus dikurangi menjadi 70\% ilmu agama dan 30\% ilmu umum. Muatan kurikulum yang demikian juga mendapat kritikan dengan berbagai alasan sehingga porsinya menjadi terbalik yakni 30\% ilmu agama dan $70 \%$ ilmu umum. Semua ini sepertinya buntut dari berbagai tafsir terhadap penyebutan madrasah sebagai sekolah berciri khas Islam. ${ }^{7}$

Terlepas dari semua itu, madrasah merupakan wadah menimba kedua ilmu tersebut yakni ilmu umum dan ilmu agama. ${ }^{8}$ Bahkan Imam Suprayogo mengatakan lembaga pendidikan ini dipandang mampu memenuhi kebutuhan masyarakat, terutama masyarakat Islam. Lembaga pendidikan ini secara konseptual ingin mengembangkan semua ranah kehidupan yang lebih sempurna, yaitu aspek spiritual, sosial dan keterampilannya sekaligus. Ranah intelektual dikembangkan lewat pelajaran umum, seperti Matematika, IPA, dan lainlain. Aspek spiritual dan sosial dikembangkan melalui pendidikan agama yang bersumberkan kitab suci dan hadits Nabi, dan keterampilan ditempuh melalui pelatihan-pelatihan di madrasah maupun di lingkungan keluarga lewat penugasan-penugasan. ${ }^{9}$ Bandingkan dengan sekolah umum tentu sangat berbeda bahkan terbalik seratus delapan puluh derajat. Walaupun

\footnotetext{
${ }^{7}$ Ciri khas Islam tersebut adalah memiliki suasana kehidupan madrasah yang agamis, memiliki sarana ibadah, penggunaan metode dan pendekatan yang agamis dan Kualifikasi guru yang harus beragama Islam dan berakhlak mulia, juga harus diletakkan dalam spectrum yang lebih luas. Maksudnya, madrasah harus mampu: (1) menjadi wahana pembinaan ruh dan praktik hidup Islami, (2) memperkokoh sistem kelembagaan madrasah agar dapat sejajar bahkan lebih dari sekolah umum, dan (3) merespon tantangan masa depan dengan memanfaatkan kemajuan IPTEK. Lebih lengkapnya Baca: Agus Maimun dan Agus Zaenul Fitri, Madrasah Unggulan Lembaga Pendidikan Alternatif di Era Kompetitif (Malang: UIN Maliki Press, 2010), hlm 4.

${ }^{8}$ Masyarakat khususnya yang kental dalam beragama Islam, dalam hal memenuhi kebutuhan pendidikan menginginkan untuk mendapatkan pendidikan umum dan agama sekaligus. Mereka ingin agar putera-puteri mereka menjadi orang yang pintar sekaligus baik. Pintar dimaknai berhasil memperoleh pengetahuan umum, seperti Matematika, IPA, Bahasa Inggris, Komputer dan sejenisnya. Sedangkan menjadi baik dimaknai mampu mengamalkan agamanya secara baik dan khusuk. Imam Suprayogo, Quo Vadis Madrasah Gagasan, Aksi dan Solusi Pembangunan Madrasah, (Yogyakarta: Hikayat, 2007), hlm. 9.

${ }^{9}$ Imam Suprayogo, Quo Vadis Madrasah Gagasan, Aksi dan Solusi Pembangunan Madrasah (Yogyakarta: Hikayat, 2007), P. 11.
} 
demikian kesan madrasah sampai saat ini tak kunjung lebih baik dibanding sekolah di tengah masyarakat.

Karenanya PGMI satu-satunya jurusan/prodi yang memahami logika doa sapu jagat yakni kebahagiaan dunia dan kebahagiaan akhirat. Kebahagiaan dunia dapat 'dinikmati' melalui kurikulum umum yang termaktub dalam mata kuliah seperti IPA, IPS, Matematika, Bahasa Indonesia dan PKn. Sedangkan kebahagiaan akhirat dapat diraih melalui kurikulum agama yang terwujud dalam mata kuliah keagamaan. Manunggalnya kedua kurikulum (mata kuliah agama-umum) tersebut dalam satu jurusan/prodi (PGMI), meminjam bahasa undangundang akan melahirkan profesionalisme guru kelas sedangkan dalam bahasa agamanya adalah kebahagiaan haqiqi (khalidi na fiiha abada).

\section{DAFTAR PUSTAKA}

Agus Maimun dan Agus Zaenul Fitri, Madrasah Unggulan Lembaga Pendidikan Alternatif di Era Kompetitif, Malang: UIN Maliki Press, 2010.

H. A. R. Tilaar, Membenahi Pendidikan Nasional, Jakarta: Rineka Cipta, 2002.

Hamzah B. Uno, Profesi Kependidikan, Problem, Solusi dan Reformasi Pendidikan di Indonesia, Jakarta: Bumi Aksara, 2008.

Imam Suprayogo, Quo Vadis Madrasah Gagasan, Aksi dan Solusi Pembangunan Madrasah, Yogyakarta: Hikayat, 2007.

Mujamil Qomar, Manajemen Pendidikan Islam Strategi Baru Pengelolaan Lembaga Pendidikan Islam, Malang: Erlangga, 2007.

Ngainun Naim, Menjadi Guru Inspiratif Memberdayakan dan Mengubah Jalan Hidup Siswa, Yogyakarta: Pustaka Pelajar, 2009.

Permen No 64 Tahun 2013 tentang Standa Isi Pendidikan Dasar dan Menengah.

peraturan menteri pendidikan nasional Republik Indonesia nomor 16 tahun 2007 tentang standar kualifikasi akademik dan kompetensi guru dan standar kompetensi guru kelas SD/MI tahun 2006. 